University of Nebraska - Lincoln

DigitalCommons@University of Nebraska - Lincoln

USDA National Wildlife Research Center - Staff Publications
U.S. Department of Agriculture: Animal and Plant Health Inspection Service

2013

\title{
Effectiveness and target-specificity of a novel design of food dispenser to deliver a toxin to feral swine in the United States
}

\author{
Tyler A. Campbell \\ United States Department of Agriculture, tcampbell@eastfoundation.net \\ Justin A. Foster \\ Texas Parks and Wildlife Department \\ Michael J. Bodenchuk \\ United States Department of Agriculture, michael.j.bodenchuk@usda.gov \\ John D. Eisemann \\ USDA/APHIS/WS National Wildlife Research Center, John.D.Eisemann@aphis.usda.gov \\ Linton Staples \\ Animal Control Technologies Australia P/L
}

See next page for additional authors

Follow this and additional works at: https://digitalcommons.unl.edu/icwdm_usdanwrc

Part of the Life Sciences Commons

Campbell, Tyler A.; Foster, Justin A.; Bodenchuk, Michael J.; Eisemann, John D.; Staples, Linton; and Lapidge, Steven J., "Effectiveness and target-specificity of a novel design of food dispenser to deliver a toxin to feral swine in the United States" (2013). USDA National Wildlife Research Center - Staff Publications. 1473.

https://digitalcommons.unl.edu/icwdm_usdanwrc/1473

This Article is brought to you for free and open access by the U.S. Department of Agriculture: Animal and Plant Health Inspection Service at DigitalCommons@University of Nebraska - Lincoln. It has been accepted for inclusion in USDA National Wildlife Research Center - Staff Publications by an authorized administrator of DigitalCommons@University of Nebraska - Lincoln. 


\section{Authors}

Tyler A. Campbell, Justin A. Foster, Michael J. Bodenchuk, John D. Eisemann, Linton Staples, and Steven J. Lapidge 


\title{
Effectiveness and target-specificity of a novel design of food dispenser to deliver a toxin to feral swine in the United States
}

\author{
Tyler A. Campbell ${ }^{\mathrm{a} *}$, Justin A. Foster ${ }^{\mathrm{b}}$, Michael J. Bodenchuk ${ }^{\mathrm{c}}$, John D. Eisemann ${ }^{\mathrm{d}}$, Linton Staples ${ }^{\mathrm{e}}$ and Steven J. Lapidge ${ }^{\mathrm{f} * *}$ \\ ${ }^{a}$ United States Department of Agriculture, Wildlife Services, National Wildlife Research Center, 2820 E University Avenue, Gainesville, \\ FL 32641, USA, ${ }^{b}$ Texas Parks and Wildlife Department, 2625 FM 1340, Hunt, TX 78024, USA; ${ }^{c}$ United States Department of \\ Agriculture, Wildlife Services, P.O. Box 690170, San Antonio, TX 78269, USA; ${ }^{d}$ United States Department of Agriculture, Wildlife \\ Services, National Wildlife Research Center, 4101 LaPorte Avenue, Fort Collins, CO 80521, USA; ${ }^{e}$ Animal Control Technologies \\ Australia P/L, 46-50 Freight Drive, Somerton VIC 3069, Australia; ${ }^{f}$ Invasive Animals Cooperative Research Centre, University \\ of Canberra, ACT 2601, Australia
}

(Received 22 March 2013; final version recieved 12 June 2013)

\begin{abstract}
There are no registered toxins available for use on Feral Swine (Sus scrofa, Linnaeus) in the United States. HOGGONE ${ }^{\circledR}$ is a proprietary bait matrix under development in Australia that delivers toxic levels of sodium nitrite to feral swine. However, one challenge is to develop a species-specific oral delivery system to deliver toxins to feral swine in the USA while minimizing non-target wildlife exposure. The HOGHOPPER ${ }^{\mathrm{TM}}$ is a lightweight and portable bait delivery system that could overcome this problem. Our objective was to compare non-toxic HOGGONE removal by wildlife that visited HOGHOPPERS during acclimation periods (doors open; free-feeding stage) and activation periods (doors closed; simulated toxic stage) at sites throughout the United States. We conducted 38 HOGHOPPER trials on private and public land in Alabama, Florida, Oklahoma, and Texas, and determined species-specific visitation and HOGGONE removal rates using motion-sensing digital camera systems. We found activated HOGHOPPERS to successfully exclude all wildlife except feral swine and Raccoon (Procyon lotor, Linnaeus). For raccoons the number of baits removed per $24 \mathrm{~h}$ was reduced by 92\% during the HOGHOPPER activation period. No other wildlife removed HOGGONE from HOGHOPPERS. During trials in which raccoon breaches occurred, an extended acclimation period was used. To minimize raccoon exposure risks, an abbreviated acclimation period of $\leq 14 \mathrm{~d}$ should be used with the HOGHOPPER. This will decrease the likelihood that raccoons learn how to access HOGGONE from the HOGHOPPER. Further experimentation is needed to demonstrate the efficacy of toxic HOGGONE at controlling feral swine populations.
\end{abstract}

Keywords: control; damage; delivery system; feral swine; HOGGONE ${ }^{\circledR}$; HOGHOPPER $^{\mathrm{TM}}$; Sus scrofa; toxic bait

\section{Introduction}

Recognizing the unprecedented range expansion of Feral Swine (Sus scrofa, Linnaeus) and their associated damage, The Wildlife Society (TWS) of the United States issued a position statement in 2011 on feral swine in North America that encourages research on methods to control, reduce, or eliminate feral swine and their negative impacts (TWS 2011). Preceding this statement, Australian researchers challenged colleagues in the United States with the following question: "Is America ready for a humane feral pig toxin?" (Lapidge et al. 2009). The simplified answer to this question is "not quite yet" and there are presently no registered toxins available for use on feral swine in the United States. One major challenge is developing a species-specific oral delivery system to deliver toxins or other pharmaceuticals to feral swine while minimizing non-target wildlife exposure. In recent years considerable advancement has been made in identifying feral swine-specific baits (Campbell et al. 2006; Campbell and Long 2007; Campbell and Long 2009a) and bait delivery systems (Long et al. 2010; Campbell et al. 2011). Here, we further address: (i) the charge of TWS for new methods to reduce feral swine damage and abundance, and (ii) the challenge from international colleagues by evaluating non-target risks associated with the Australian developed HOGGONE $^{\circledR}$ feral swine baits delivered through the HOGHOPPER $^{\mathrm{TM}}$.

HOGGONE is a proprietary bait matrix developed by Animal Control Technologies Australia (ACTA) and the Invasive Animals Cooperative Research Centre that delivers toxic levels of sodium nitrite to feral swine (Lapidge et al. 2012). Bait-delivered nitrite is patented as a vertebrate pesticide by ACTA in Australia, with pending patents in the United States and other countries (Lapidge et al. 2012). Nitrite toxicosis occurs through methaemoglobinemia, which results in depletion of oxygen to vital organs (Lapidge et al. 2012). Feral swine receiving lethal doses of nitrite display mild symptoms lasting less than 30 minutes and die in approximately 1.5 hours following ingestion of a lethal dose (Cowled et al. 2008; Lapidge et al. 2012), which are characteristics of a humane toxin (IMVS 2010).

\footnotetext{
*Corresponding author. Email: tcampbell@eastfoundation.net

Present address: East Wildlife Foundation, 200 Concord Plaza Drive, Suite 410, San Antonio, TX 78216, USA.

**Present address: Rural Solutions SA, GPO Box 1671, Adelaide SA 5001, Australia.
} 
The HOGHOPPER is a lightweight $(22.7 \mathrm{~kg})$ and portable bait delivery system manufactured for ACTA that is designed to deliver baits specifically to feral swine. In Australia, the HOGHOPPER is used only on properties containing livestock or in national parks to deliver baits specifically to feral swine (Lapidge et al. 2012). In the United States, a feral swine-specific bait delivery system is needed in virtually all environments, because non-target wildlife readily remove and consume ground-deployed or buried baits intended for feral swine (Campbell et al. 2006; Campbell and Long 2007; Campbell and Long 2009a). Evaluations related to the feral swine-specific characteristics of the HOGHOPPER have not occurred in the United States and are needed.

Our objectives were to: (i) compare HOGGONE removal by wildlife visiting HOGHOPPERS during acclimation periods (doors open; free feeding stage) and activation periods (doors closed), and (ii) evaluate acceptance of HOGGONE formulations by feral swine in captive and field settings. Given minimal bait removal by non-target wildlife using the HOGHOPPER in Australia (Lapidge et al. 2012), we hypothesized that HOGGONE removal by non-target wildlife would be markedly reduced during the activation period compared to acclimation period. In addition, we sought to make recommendations aimed at increasing the success of baiting campaigns in the United States.

\section{Methods}

\subsection{Study areas}

Our HOGHOPPER trials occurred on private and public land in Alabama, Florida, Oklahoma, and Texas with diverse land uses. In Alabama, trials occurred in Baldwin County $\left(30^{\circ} 53^{\prime} \mathrm{N}, 87^{\circ} 46^{\prime} \mathrm{W}\right.$, mixed forest). In Florida, trials occurred in Alachua $\left(29^{\circ} 42^{\prime} \mathrm{N}, 82^{\circ} 20^{\prime} \mathrm{W}\right.$, coniferous forest) and Putnam $\left(29^{\circ} 40^{\prime} \mathrm{N}, 82^{\circ} 06^{\prime} \mathrm{W}\right.$, coniferous forest) counties. In Oklahoma, trials occurred in Murray County $\left(34^{\circ} 31^{\prime} \mathrm{N}, 96^{\circ} 51^{\prime} \mathrm{W}\right.$, mixed grassland). In Texas, trials occurred in Childress $\left(34^{\circ} 31^{\prime} \mathrm{N}, 100^{\circ} 10^{\prime} \mathrm{W}\right.$, rolling plains), Hall $\left(34^{\circ} 28^{\prime} \mathrm{N}, 100^{\circ} 42^{\prime} \mathrm{W}\right.$, rolling plains), Hill $\left(32^{\circ} 01^{\prime} \mathrm{N}, 97^{\circ} 08^{\prime} \mathrm{W}\right.$, cross timbers and prairies), Jim Wells $\left(27^{\circ} 47^{\prime} \mathrm{N}, 98^{\circ} 02^{\prime} \mathrm{W}\right.$, south Texas plains), Kerr $\left(30^{\circ} 05^{\prime} \mathrm{N}\right.$, $97^{\circ} 27^{\prime} \mathrm{W}$, Edwards Plateau), Kleberg $\left(27^{\circ} 25^{\prime} \mathrm{N}, 97^{\circ} 41^{\prime} \mathrm{W}\right.$, gulf coast prairies and marshes), Lee $\left(30^{\circ} 17^{\prime} \mathrm{N}, 96^{\circ} 57^{\prime} \mathrm{W}\right.$, blackland prairies), Mason $\left(30^{\circ} 39^{\prime} \mathrm{N}, 99^{\circ} 16^{\prime} \mathrm{W}\right.$, Edwards Plateau), Nueces $\left(27^{\circ} 46^{\prime} \mathrm{N}, 97^{\circ} 28^{\prime} \mathrm{W}\right.$, gulf coast prairies and marshes), Palo Pinto $\left(32^{\circ} 42^{\prime} \mathrm{N}, 98^{\circ} 23^{\prime} \mathrm{W}\right.$, cross timbers and prairies), Robertson $\left(31^{\circ} 00^{\prime} \mathrm{N}, 96^{\circ} 29^{\prime} \mathrm{W}\right.$, post oak savannah), San Patricio $\left(27^{\circ} 59^{\prime} \mathrm{N}, 97^{\circ} 31^{\prime} \mathrm{W}\right.$, gulf coast prairies and marshes), and Uvalde $\left(29^{\circ} 20^{\prime} \mathrm{N}\right.$, $99^{\circ} 48^{\prime} \mathrm{W}$, south Texas plains) counties. Mean annual precipitation at trial locations ranged from 57 to $166 \mathrm{~cm}$ (National Climatic Data Center, http://www.ncdc.noaa. gov), and at all sites feral swine populations were at an abundance to warrant damage control activities. Overstory and understory vegetation were dominated by a diverse assemblage of forbs, grasses, vines, shrubs, cacti, ferns, and trees. Numerous non-target mammals were present, depending upon specific location, including Raccoons
(Procyon lotor, Linnaeus), Collared Peccaries (Tayassu tajacu, Linnaeus), White-tailed Deer (Odocoileus virginianus, Zimmermann), Striped Skunks (Mephitis mephitis, Schreber), Opossums (Didelphis virginiana, Kerr), Coyotes, (Canis latrans, Say), Armadillos (Dasypus novemcinctus, Illiger), Badgers (Taxidea taxus, Schreber), Black Bears (Ursus americanus, Pallas), Bobcats (Lynx rufus, Schreber), Grey Foxes (Urocyon cinereoargenteus, Schreber), Red Foxes (Vulpes vulpes, Linnaeus), lagomorphs, rodents, and cattle.

Our HOGGONE formulation trials occurred at the Texas Parks and Wildlife Department's Captive Feral Swine Research and Demonstration Facility at the Kerr Wildlife Management Area (KWMA) and in field settings in Childress and Hall counties in Texas. Mean annual precipitation at locations for our field trials was $57 \mathrm{~cm}$ (National Climatic Data Center, http://www.ncdc.noaa.gov).

\subsection{HOGHOPPER trials}

Our trials were run from December 2010 to June 2012. During each trial, we used non-toxic HOGGONE baits (ACTA P/L, Somerton, Victoria, Australia) to attract feral swine and other wildlife to HOGHOPPERS (ACTA P/L, Somerton, Victoria, Australia). Our baits were grainbased with fish flavouring added to the proprietary mixture. Baits were moist, cylindrical in shape, $5 \times 4 \mathrm{~cm}$, and weighed approximately $70 \mathrm{~g}$ (Figure 1).

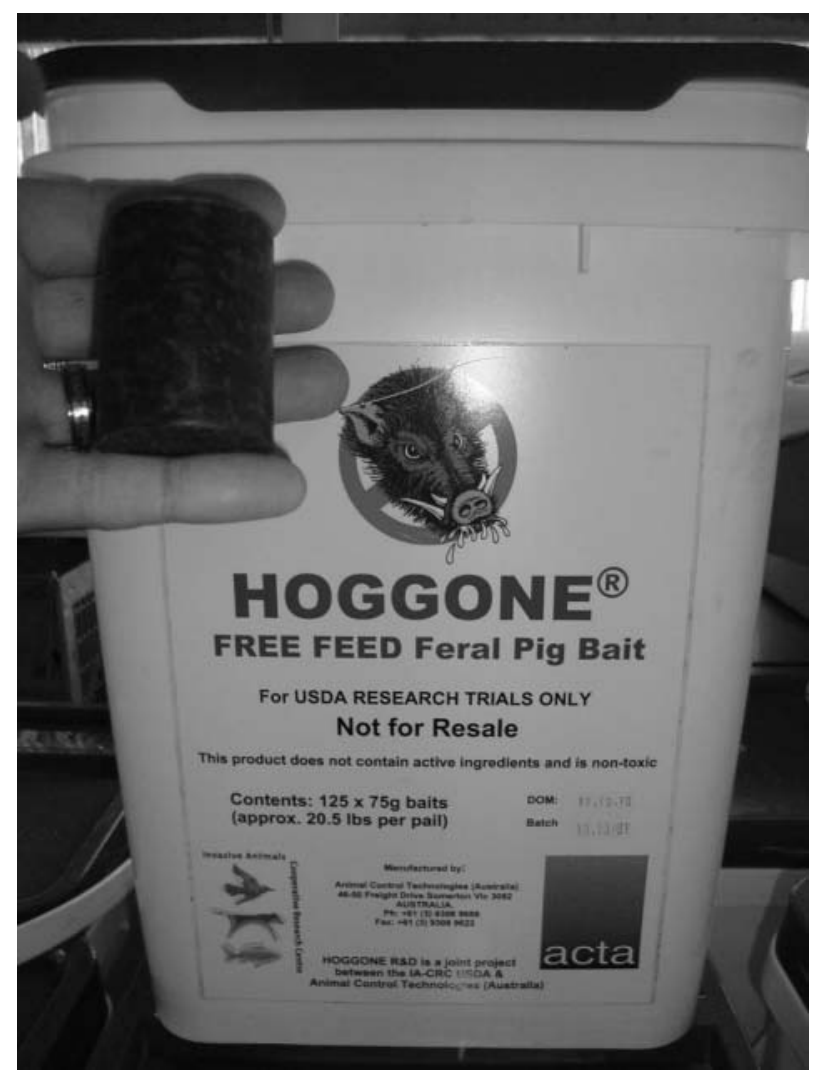

Figure 1. Non-toxic HOGGONE ${ }^{\circledR}$ baits for Feral Swine (Sus scrofa) used in trials conducted in Alabama, Florida, Oklahoma, and Texas from December 2010 to June 2012. 
Throughout each trial, we used HOGHOPPER feeders. HOGHOPPERS were $70 \times 60 \times 70 \mathrm{~cm}$ boxes made of aluminium. Two opposing sides of the HOGHOPPER were gravity-activated guillotine-style doors that can be opened by feral swine and other wildlife by lifting a door handle upward. In addition, doors can be locked in an open position at a height of $13 \mathrm{~cm}$, allowing wildlife to acclimate to lifting the door to access bait (Figure 2). HOGHOPPERS were filled with bait or other feed through a top door $(22 \times 53 \mathrm{~cm})$ that can be secured to eliminate wildlife access. The base of each HOGHOPPER had four eyelets to secure units to the ground with stakes or T-posts. HOGHOPPERS can hold approximately 250 of the 70-g HOGGONE baits.

We distributed one HOGHOPPER per trial in feral swine habitat, including areas with free water and thick cover, and sign of recent feral swine activity, such as rooting. All HOGHOPPER trial locations were georeferenced (GPSmap 60, Garmin, Olathe, Kansas) to ensure that the minimum spacing was at least $5 \mathrm{~km}$ to better ensure spatial independence (Campbell et al. 2010).

During each trial, we monitored HOGHOPPERS continuously for $\leq 57$ nights (though typically $\leq 21$ nights, see below) using two motion-sensing digital camera systems (Rapidfire ${ }^{\mathrm{TM}}$ or Hyperfire ${ }^{\mathrm{TM}}$ Professional Editions, Reconyx Incorporated, Holmen, Wisconsin). We operated camera systems at their highest sensitivity setting, and programmed the units to capture three images per trigger with no delay between triggers. We set up camera systems 3-5m from HOGHOPPERS, with one camera system directly facing each of the two doors. We used vegetation or artificial structures as camera supports.
During the first 7-14 nights of each trial, we secured HOGHOPPERS in an open position (Figure 2) to permit access by wildlife and allow animals to acclimatize to feeding from the unit. Hereafter, we refer to this timeframe as the "acclimation period". On night-one of the acclimation period, we baited HOGHOPPERS with $11.3 \mathrm{~kg}$ of whole kernel corn and 20 HOGGONE baits. Throughout the remainder of the acclimation period, we revisited HOGHOPPERS to check baits and camera systems daily from $0800 \mathrm{~h}$ to $1100 \mathrm{~h}$, recording the presence or absence of baits, condition of baits, and number of images captured. We replenished whole kernel corn during the first three nights of use by wildlife during the acclimation period, as needed. Missing HOGGONE baits were replenished to maintain 20 baits each night of the acclimation period. During the final four nights of the acclimation period we provided only HOGGONE baits.

Following the acclimation period, we activated HOGHOPPERS by closing the doors for 4-13 nights. Hereafter, we refer to this timeframe as the "activation period". On night-one of the activation period, we baited HOGHOPPERS with 20 HOGGONE baits only. Throughout the remainder of the activation period, we revisited HOGHOPPERS to check baits and camera systems daily from $0800 \mathrm{~h}$ to $1100 \mathrm{~h}$, recording the presence or absence of baits, condition of baits, and number of images captured. Missing HOGGONE baits were replenished to maintain 20 baits each night.

We determined species-specific visitation and removal rates of HOGGONE baits at hourly intervals through digital image analysis. For each trial, we generated mean removal values for the last four nights of the acclimation

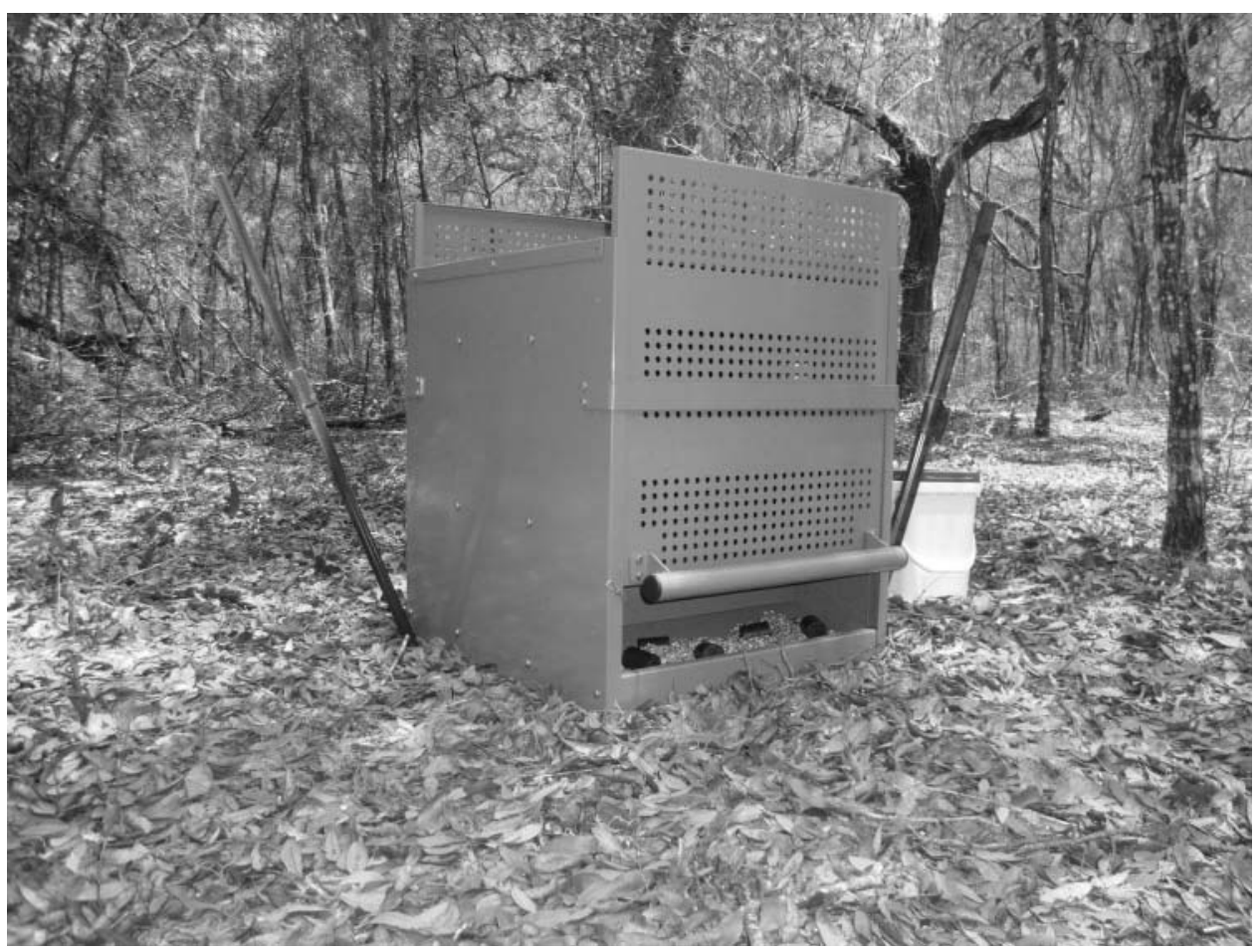

Figure 2. The HOGHOPPER ${ }^{\mathrm{TM}}$ oral delivery system for Feral Swine (Sus scrofa), with doors locked in an open position, used in trials conducted in Alabama, Florida, Oklahoma, and Texas from December 2010 to June 2012. 
period and the first four nights of the activation period, being timeframes during which only HOGGONE was offered. We compared the maximum number of individuals removing baits at one time by species and number of bait removal events per 24 hours by species between the acclimation and activation periods with paired signed rank tests using PROC UNIVARIATE of the of the SAS program (Schulman 1992). We determined statistical significance at $\alpha=0.05$. All animal monitoring and handling procedures conducted in field settings were approved by the Institutional Animal Care and Use Committee at the National Wildlife Research Center and humane practices were followed (Permit No. QA-1767).

\subsection{HOGGONE formulation trials}

Our field trials occurred from February to May 2012. We followed procedures described above in the "HOGHOPPER trials" section related to HOGHOPPER distribution and georeferencing, HOGHOPPER monitoring with motion sensing digital camera systems, and trial acclimation and activation periods. However, our formulation trials had two notable distinctions. First, we paired two HOGHOPPERS at $50 \mathrm{~m}$, rather than spacing them at $\geq 5 \mathrm{~km}$ and we conducted two trials concurrently at the same location. Second, within one of the paired HOGHOPPERS we used bait 4, which is a corn-flavoured HOGGONE, and within one of the paired HOGHOPPERS we used bait5, the original fish-flavoured HOGGONE (Table 1). We determined species-specific visitation and removal rates of HOGGONE baits at hourly intervals through digital image analysis. For each trial, we generated mean removal values for the last four nights of the acclimation period and the first four nights of the activation period, being timeframes during which only HOGGONE baits were offered. We reported descriptive statistics pertaining to the maximum number of individuals removing baits at one time by bait type and number of bait removal events per 24 hours by bait type between the acclimation and activation periods.
Our captive trials occurred from May to June 2012. We used 38 group-housed captive, but wild-caught, feral swine as study subjects in a 2-ha enclosure where food, water, and cover were provided. Captive feral swine were of mixed sex and age, with 19 males $(22.7-48.9 \mathrm{~kg})$ and 19 females $(20.6-44.4 \mathrm{~kg})$ represented. We conducted 4 two-choice trials, each consisting of $5 \mathrm{~d}$ of observation. Throughout each trial, we presented two different nontoxic HOGGONE bait formulations, with characteristics similar to those described above, with the exception that baits 1-4 were corn-flavoured. Together, we evaluated five different bait formulations: (i) grey-coloured corn flavoured bait with $1.2 \%$ hardening agent and no sweetener; (ii) grey-coloured corn flavoured bait with $1.5 \%$ hardening agent and no sweetener; (iii) grey-coloured corn flavoured bait with $1.5 \%$ hardening agent and a sweetener; (iv) naturally coloured corn-flavoured bait with $1.5 \%$ hardening agent and a sweetener; and (v) greycoloured fish-flavoured bait with $1.5 \%$ hardening agent and no sweetener. We deployed baits 1 and 2 during Trial 1, baits 2 and 3 during Trial 2, baits 3 and 4 during Trial 3, and baits 2 and 5 during Trial 4. In addition to HOGGONE, we provided $20 \mathrm{~kg}$ of pelleted feed (Hunt Deer Feed, Behrends Feed, Harper, Texas) daily during Trial $1,30 \mathrm{~kg}$ of pelleted feed daily during Trials 2 and 3, and pelleted feed ad libitum during Trial 4 at a feeding station approximately $150 \mathrm{~m}$ from the HOGHOPPERS mentioned below.

We deployed baits in two HOGHOPPERS maintained in the open position (similar to the acclimation period described above), one for each bait type. We placed the HOGHOPPERS approximately $150 \mathrm{~m}$ apart and deployed 50 baits in each HOGHOPPER daily. Within trials, we alternated the deployment of bait type by HOGHOPPER daily. We monitored HOGHOPPERS continuously throughout each trial using motion sensing Rapidfire digital camera systems. We operated and set up camera systems as previously described. We recorded the number of baits removed by bait type and downloaded digital images daily.

Table 1. Mean $( \pm$ SE) maximum number of individuals removing baits at one time by species and number of bait removal events per 24 hours by species during HOGHOPPER ${ }^{\mathrm{TM}}$ trials $(n=28)$ conducted in Alabama, Florida, Oklahoma, and Texas from December 2010 to June 2012

\begin{tabular}{|c|c|c|c|c|c|c|c|c|c|c|}
\hline \multirow[b]{3}{*}{ Species $^{\mathrm{a}}$} & \multicolumn{5}{|c|}{ Maximum number of individuals removing baits at one time } & \multicolumn{5}{|c|}{ Number of baits removed per 24 hours } \\
\hline & \multicolumn{2}{|c|}{$\begin{array}{l}\text { Acclimation } \\
\text { period }\end{array}$} & \multicolumn{2}{|c|}{$\begin{array}{l}\text { Activation } \\
\text { period }\end{array}$} & \multirow[b]{2}{*}{ Reduction $(\%)$} & \multicolumn{2}{|c|}{$\begin{array}{l}\text { Acclimation } \\
\text { period }\end{array}$} & \multicolumn{2}{|c|}{$\begin{array}{l}\text { Activation } \\
\text { period }\end{array}$} & \multirow[b]{2}{*}{ Reduction (\%) } \\
\hline & Mean & SE & Mean & SE & & Mean & SE & Mean & $\mathrm{SE}$ & \\
\hline Feral Swine (14) & 6.5 & 1.4 & 4.8 & 1.5 & 26 & 10.0 & 1.9 & 6.0 & 1.8 & 40 \\
\hline Raccoon (19) & 3.2 & 0.4 & 0.5 & 0.2 & 84 & 6.3 & 1.1 & 0.5 & 0.3 & 92 \\
\hline Opossum (4) & 1.3 & 0.3 & 0 & & 100 & 1.0 & 0.3 & 0 & & 100 \\
\hline Striped Skunk (2) & 1.0 & 0 & 0 & & 100 & 1.4 & 0.6 & 0 & & 100 \\
\hline White-tailed Deer (1) & 2.0 & & 0 & & 100 & 1.0 & & 0 & & 100 \\
\hline Coyote (1) & 1.0 & & 0 & & 100 & 0.5 & & 0 & & 100 \\
\hline
\end{tabular}

$\mathrm{SE}=$ standard error.

${ }^{a}$ Number of trials with baits removed in parentheses. 
We analysed data from each two-choice trial independently and considered each day of a trial to be a replication. For each trial, we reported descriptive statistics pertaining to the number of baits removed, and from analysis of digital images, the proportions of days in which all baits were removed first by bait type. We compared the time taken to consume all baits in minutes (calculated by subtracting the time at which the first bait was removed from the time at which the last bait was removed) with pooled $t$-tests using PROC TTEST of the of the SAS program (Schulman 1992). We determined statistical significance at $\alpha=0.05$. All capture, handling, and housing procedures conducted in captivity were approved by the Institutional Animal Care and Use Committee at the KWMA and humane practices were followed (Permit No. 11051020121).

\section{Results}

\subsection{HOGHOPPER trials}

We initiated 38 trials and collected usable data during 28 trials. For the 10 initiated trials in which unusable data were recorded, 7 trials (18\% of total) did not observe wildlife removing HOGGONE baits from HOGHOPPERS, and during 3 trials the data were not properly recorded. Of the trials with usable data, 1 was conducted in Alabama, 3 were conducted in Florida, 1 was conducted in Oklahoma, and 23 were conducted in Texas. During the acclimation period, we found HOGGONE bait removal by feral swine (14 trials), raccoons (19 trials), opossums (4 trials), striped skunks ( 2 trials), and by whitetailed deer and coyotes in one trial each (Table 1). During both periods other non-target wildlife, such as Collared Peccaries, Armadillos, Black Bears, Grey Foxes, lagomorphs, Turkey Vultures (Cathartes aura, Linnaeus), and Wild Turkeys (Meleagris gallopavo, Linnaeus), were observed visiting HOGHOPPERS, particularly during the early phases of the acclimation period to remove corn, but not removing HOGGONE.

We found activated HOGHOPPERS to successfully exclude all wildlife except feral swine and raccoons
(Table 1). In addition, for raccoons, we found differences in maximum number of individuals removing baits at one time $\left(S_{18}=76.5, P<0.001\right)$ and number of baits removed per 24 hours $\left(S_{18}=95, P<0.001\right)$ between the acclimation and activation periods. The maximum number of raccoons removing baits at one time and number of baits removed per 24 hours was greater during the acclimation period than during the activation period. Raccoons only removed HOGGONE baits in the activation period during 4 trials and the maximum number of raccoons removing baits at one time and the number of baits removed per 24 hours was reduced by $84 \%$ and $92 \%$, respectively. For feral swine, we found no difference in maximum number of individuals removing baits at one time $\left(S_{13}=20, P=\right.$ 0.122 ) between the acclimation and activation periods. However, we found the number of baits removed per 24 hours for feral swine differed $\left(S_{13}=41, P=0.002\right)$, with more baits being removed during the acclimation period than during the activation period.

\subsection{HOGGONE formulation trials}

In captivity, we found high HOGGONE acceptance by feral swine during Trials $1-3$, with all baits being removed daily (Table 2). During Trial 4, feral swine removed all of the type- 2 baits daily and an average of 46.6 of the type- 5 baits daily; during two days, feral swine did not remove all of the type- 5 baits, providing evidence that feral swine preferred corn-flavoured baits. We observed no trends in the proportion of days in which all baits were removed first during Trials 1-3, with either 2 of 5 days or 3 of 5 days recorded for each bait type. However, during Trial 4 feral swine consumed all of the type- 2 baits first on 4 of 5 days. In addition, we found no differences in time taken to remove all baits by bait type during Trial $1\left(t_{8}=-1.20\right.$, $P=0.266)$, Trial $2\left(t_{8}=-0.96, P=0.367\right)$, Trial $3\left(t_{8}=\right.$ $0.74, P=0.478)$, or Trial 4 ( $\left.t_{6}=-0.18, P=0.866\right)$; however, as noted, not all of the type- 5 baits were removed daily during Trial 4.

We conducted two paired field trials, during which feral swine and no other wildlife were observed removing

Table 2. Mean $( \pm \mathrm{SE})$ number of baits removed, time taken to remove all baits (min), and proportion of days in which all baits were removed first by trial and bait type during HOGGONE formulation trials conducted at the Texas Parks and Wildlife Department's Captive Feral Swine Research and Demonstration Facility at the Kerr Wildlife Management Area from May to June 2012.

\begin{tabular}{|c|c|c|c|c|c|c|}
\hline \multirow[b]{2}{*}{ Trial } & \multirow[b]{2}{*}{ Bait type } & \multicolumn{2}{|c|}{$\begin{array}{l}\text { Number of baits } \\
\text { removed }\end{array}$} & \multicolumn{2}{|c|}{$\begin{array}{l}\text { Time taken to remove } \\
\text { all baits }(\mathrm{min})^{\mathrm{a}}\end{array}$} & \multirow{2}{*}{$\begin{array}{l}\text { Proportion of days in which all } \\
\text { baits were removed first }\end{array}$} \\
\hline & & Mean & $\mathrm{SE}$ & Mean & SE & \\
\hline \multirow[t]{2}{*}{1} & 1 & 50.0 & 0.0 & 5.6 & 0.5 & $3 / 5$ \\
\hline & 2 & 50.0 & 0.0 & 7.4 & 1.4 & $2 / 5$ \\
\hline \multirow[t]{2}{*}{2} & 2 & 50.0 & 0.0 & 5.3 & 0.3 & $3 / 5$ \\
\hline & 3 & 50.0 & 0.0 & 5.9 & 0.6 & $2 / 5$ \\
\hline \multirow[t]{2}{*}{3} & 3 & 50.0 & 0.0 & 100.3 & 90.1 & $3 / 5$ \\
\hline & 4 & 50.0 & 0.0 & 32.4 & 14.4 & $2 / 5$ \\
\hline \multirow[t]{2}{*}{4} & 2 & 50.0 & 0.0 & 150.8 & 83.1 & $4 / 5$ \\
\hline & 5 & 46.6 & 2.2 & 174.1 & 76.1 & $1 / 5$ \\
\hline
\end{tabular}

${ }^{a}$ Calculated by subtracting the time at which the first bait was removed from the time at which the last bait was removed. During trial 4 , for bait type 5 Feral Swine only removed all baits on 3 of 5 nights. Consequently, mean is for 3 nights only. 
Table 3. Mean ( \pm SE) maximum number of individuals removing baits at one time by bait type and number of bait removal events per 24 hours by bait type during HOGGONE ${ }^{\circledast}$ formulation field trials conducted in Childress and Hall counties, Texas from February to May 2012.

\begin{tabular}{|c|c|c|c|c|c|c|c|c|c|c|}
\hline \multirow[b]{3}{*}{ Bait type } & \multicolumn{5}{|c|}{ Maximum number of individuals removing baits at one time } & \multicolumn{5}{|c|}{ Number of baits removed per 24 hours } \\
\hline & \multicolumn{2}{|c|}{$\begin{array}{l}\text { Acclimation } \\
\text { period }\end{array}$} & \multicolumn{2}{|c|}{$\begin{array}{l}\text { Activation } \\
\text { period }\end{array}$} & \multirow[b]{2}{*}{ Reduction (\%) } & \multicolumn{2}{|c|}{$\begin{array}{l}\text { Acclimation } \\
\text { period }\end{array}$} & \multicolumn{2}{|c|}{$\begin{array}{l}\text { Activation } \\
\text { period }\end{array}$} & \multirow[b]{2}{*}{ Reduction $(\%)$} \\
\hline & Mean & $\mathrm{SE}$ & Mean & SE & & Mean & $\mathrm{SE}$ & Mean & SE & \\
\hline 4 (corn-flavoured) & 11.5 & 1.5 & 10.5 & 1.5 & 9 & 20.0 & 0 & 17.1 & 0.1 & 15 \\
\hline 5 (fish-flavoured) & 10.5 & 0.5 & 11.5 & 1.5 & 0 & 17.6 & 2.4 & 15.4 & 2.1 & 13 \\
\hline
\end{tabular}

$\mathrm{SE}=$ standard error

HOGGONE from HOGHOPPERS. Similar to our captive trials, feral swine acceptance of both baits was high during our field trials (Table 3 ). We found the maximum number of individuals removing corn-flavoured and fish-flavoured baits at one time during the activation period to be 10.5 and 11.5 , respectively. Similarly, we found the number of corn-flavoured and fish-flavoured baits removed per 24 hours to be 17.1 and 15.4 , respectively. The mean maximum number of feral swine removing baits at one time for the corn-flavoured and fish-flavoured baits was reduced by only $9 \%$ and $0 \%$, respectively, from the acclimation period to the activation period. Also, the number of baits removed per 24 hours for the corn-flavoured and fish-flavoured baits was reduced by $15 \%$ and $13 \%$, respectively, from the acclimation period to the activation period.

\section{Discussion}

Overall use of HOGHOPPERS by wildlife during our trials was encouraging. For example, $82 \%$ of trials recorded HOGGONE removal by wildlife. At most locations, wildlife habituated to the presence of HOGHOPPERS and removed baits during the acclimation period. As with other studies involving feral swine oral delivery systems in the United States (Campbell et al. 2011), raccoons were the primary non-target species that removed baits during the acclimation period, with $68 \%$ of trials recording this behaviour. Whereas, feral swine were observed removing baits during the acclimation period in $50 \%$ of the trials. Our experimental protocol did not allow field personnel to move HOGHOPPERS once they had been deployed. In practice, moving HOGHOPPERS during periods of inactivity should increase overall use by feral swine. Also, using corn-flavoured HOGGONE rather than fish-flavoured HOGGONE may facilitate feral swine use of HOGHOPPERS.

When activated, HOGHOPPERS prohibited access to HOGGONE by opossums, striped skunks, white-tailed deer, and coyotes. Also, many other non-target species were present during trials, including collared peccaries, which did not remove baits during either the acclimation or activation periods, providing evidence that the HOGHOPPER-HOGGONE oral delivery system was effective at excluding these species as well. A species of particular concern is the Black Bear, with its omnivorous diet similar to feral swine. We conducted 4 trials at sites within the range of black bears and observed no bait removal; however, captive black bears maintained in a zoo environment have breached the HOGHOPPER (T.A. Campbell, USDA APHIS Wildlife Services, unpublished data). In practice, diligent monitoring of HOGHOPPERS when units are deployed within the range of black bears will reduce bait exposure risks.

Similarly, when activated, HOGHOPPERS effectively excluded raccoons from HOGGONE, with the maximum number baits removed at one time being reduced by $84 \%$ and the number of baits removed per 24 hours being reduced by $92 \%$. However, breaches occurred by raccoons during $14 \%$ of trials. During the 4 trials in which raccoon breaches occurred, field personnel used an acclimation period of 30-36 days, instead of $\leq 14$ days. This extended acclimation period was performed to facilitate use by feral swine. We believe the extended duration of the acclimation period allowed raccoons time to learn how to access baits from the HOGHOPPER.

We recommend in situations where feral swine are not active at HOGHOPPERS that units are moved to alternate locations rather than extending the acclimation period beyond 14 days. Furthermore, during the 4 trials in which raccoon breaches occurred, no feral swine removed baits. If feral swine would have been active at these HOGHOPPERS, then raccoon visitation and use could have been reduced or eliminated through competitive interactions with feral swine.

Feral swine readily removed HOGGONE from HOGHOPPERS during the activation period, though the number of baits removed per 24 hours was less during this period. During 5 trials we observed feral swine removing baits during the acclimation period, but not during the activation period. For these trials, there was no apparent seasonal relationship, with trials occurring in January, March, May, June, and December. Again, using cornflavoured HOGGONE rather than fish-flavoured HOGGONE may motivate feral swine to use HOGHOPPERS during the activation period.

The HOGHOPPER performed similarly to other feral swine oral delivery systems in field trials conducted in the United States. For example, in southern Texas researchers found bait removal rates to be reduced following 
activation of the Boar-Operated-System BOS $^{\mathrm{TM}}$, Food and Environment Research Agency, Sand Hutton, York, United Kingdom) by $10 \%$ for feral swine and $100 \%$ for non-target wildlife, though raccoons removed baits that were spilled by feral swine (Campbell et al. 2011). The HOGHOPPER has a greater bait capacity (approximately 250 HOGGONE baits) than the BOS (approximately 10 HOGGONE baits), which is important if attempting to deliver baits to entire sounders, particularly in remote environments that may not be readily accessible.

Our captive formulation trials were designed to determine feral swine's preference for percentage hardening agent (Trial 1), sweetener additive (Trial 2), and colour additive (Trial 3) among corn-flavoured HOGGONE. Though inference from our captive trials was limited because we provided pelleted feed, feral swine did not discriminate in their acceptance of baits during these trials. There was evidence that captive feral swine preferred corn-flavoured HOGGONE over fish-flavoured HOGGONE during Trial 4, with all of the corn-flavoured baits being removed on 5 of 5 days, compared to all fishflavoured baits being removed on only 3 of 5 days. However, feral swine under field conditions accepted both corn-flavoured HOGGONE and fish-flavoured HOGGONE. Site-specific variation may occur in the preferred bait flavour for feral swine. Given that corn is widely used in feral swine management in the United States (Campbell and Long 2009b; Williams et al. 2011) and is more readily available, corn-flavoured baits may be more universally accepted by feral swine than fish-flavoured baits.

Based on data from our experimental trials with the HOGHOPPER-HOGGONE oral delivery system, several recommendations can be made that will increase the success of baiting campaigns. First, to minimize raccoon exposure risks, an abbreviated acclimation period of $\leq 14$ days should be used. This will decrease the likelihood that raccoons learn how to access HOGGONE from the HOGHOPPER during the activation period. The goal with the acclimation period is for feral swine to become comfortable in feeding from the HOGHOPPER. This often occurs after 3-4 days of feeding from units, after which time HOGHOPPERS should be activated. Prebaiting with corn, or other bait, without HOGHOPPERS present should occur prior to the acclimation period and alternate sites should be available after HOGHOPPERS are deployed. Second, to minimize exposure risks to black bears when conducting campaigns in areas where they occur, monitor HOGHOPPERS with motion sensing digital camera systems during the acclimation period. In the event that black bears are detected, discontinue baiting of site and move the HOGHOPPER to another location. Also, black bear activity and HOGGONE removal will be reduced during the hibernation period, which is the optimal season for baiting campaigns in areas with black bears. Third, initiate baiting campaigns during periods of resource scarcity. Depending upon location, this may occur during winter when food is limited and hard-mast resources have been exhausted, or during summer when water and food are limited and feral swine are congregated near sources of water. Fourth, as with feral swine trapping campaigns, maintain multiple prebaited sites and move HOGHOPPERS to sites with high feral swine activity and use (Long and Campbell 2012). Bait used during prebaiting should be non-toxic HOGGONE, corn, or other grain. If feral swine discontinue using a site after a HOGHOPPER is deployed, then move the HOGHOPPER to an alternate site. This will provide the practitioner with flexibility when conducting baiting campaigns.

Here we demonstrate the feral swine-specific characteristics of non-toxic HOGGONE when delivered through the HOGHOPPER. Additional research is needed on toxic HOGGONE before HOGHOPPERS will be permitted for use in management applications in the United States. Specifically, further experimentation is needed demonstrating the efficacy of toxic HOGGONE at controlling feral swine populations under a variety of field conditions and habitat types. Such controlled experiments require an experimental use permit from the US Environmental Protection Agency, which is being pursued.

\section{Acknowledgements}

The study was funded by United States Department of Agriculture (USDA), Animal and Plant Health Inspection Service, Wildlife Services program, the Invasive Animals Cooperative Research Centre, Animal Control Technologies Australia P/L, and the Texas Parks and Wildlife Department. We thank the landowners and managers that granted property access. We are indebted to the many personnel who tirelessly assisted with data collection. The USDA does not endorse products mentioned in this study.

\section{References}

Campbell TA, Lapidge SJ, Long DB. 2006. Using baits to deliver pharmaceuticals to feral swine in southern Texas. Wildl Soc Bull. 34:1184-1189.

Campbell TA, Long DB. 2007. Species-specific visitation and removal of baits for delivery of pharmaceuticals to feral swine. J Wildl Dis. 43:485-491.

Campbell TA, Long DB. 2009a. Strawberry-flavored baits for pharmaceutical delivery to feral swine. J Wildl Manage. 73:615-619.

Campbell TA, Long DB. 2009b. Feral swine damage and damage management in forested ecosystems. For Ecol Manage. 257:2319-2326.

Campbell TA, Long DB, Leland BR. 2010. Feral swine behavior relative to aerial gunning in southern Texas. J Wildl Manage. 74:337-341.

Campbell TA, Long DB, Massei G. 2011. Efficacy of the BoarOperated-System to deliver baits to feral swine. Prev Vet Med. 98:243-249.

Cowled BD, Elsworth P, Lapidge SJ. 2008. Additional toxins for feral pig (Sus scrofa) control: identifying and testing Achilles' heels. Wildl Res. 35:651-662.

Institute of Medical and Veterinary Science [IMVS]. 2010. Assessing the humaneness and efficacy of a new feral pig bait in domestic pigs. Report for the Australian Government Department of the Environment, Water, Heritage and the Arts. Canberra, Australia. Available at: $<$ http://www.environment.gov.au/biodiversity/invasive/publications/pubs/pigsimvs-report.pdf $>$ (accessed 14 September 2012).

Lapidge S, Wishart J, Smith M, Staples L. 2009. Is America ready for a humane feral pig 'toxin'? Proc Wildl Damage Manage Conf. 13:49-59. 
Lapidge S, Wishart J, Staples L, Fagerstone K, Campbell T, Eisemann J. 2012. Development of a feral swine toxic bait $\left(\right.$ HOGGONE $^{\circledR}$ ) and bait hopper (HOGHOPPER ${ }^{\mathrm{TM}}$ ) in Australia and the USA. Proc Wildl Damage Manage Conf. 14:19-24.

Long DB, Campbell TA. 2012. Box traps for feral swine capture: a comparison of gate styles in Texas. Wildl Soc Bull. 36:741-746.

Long DB, Campbell TA, Massei G. 2010. Evaluation of feral swine-specific feeder systems. Rangelands 32(2):8-13.
Schulman RS. 1992. Statistics in plain English with computer application. New York: Chapman and Hall.

The Wildlife Society [TWS]. 2011. Final position statement on feral swine in North America. The Wildlife Society, Bethesda, Maryland, USA. Available at: <http://joomla. wildlife.org/documents/positionstatements/feral_swine_080 211.pdf $>$ (accessed 27 September 2012).

Williams BL, Holtfreter RW, Ditchkoff SS, Grand JB. 2011. Efficiency of time-lapse intervals and baits for camera surveys of wild pigs. J Wildl Manage. 75:655-659. 